\title{
Immigrant Spanish as Liability or Asset? Generational Diversity in Language Ideologies at School
}

\author{
Elaine Allard \\ Katherine Mortimer \\ Sarah Gallo \\ Holly Link \\ University of Pennsylvania \\ Stanton Wortham \\ University of Pennsylvania, stanton.wortham@bc.edu
}

Follow this and additional works at: https://repository.upenn.edu/gse_pubs

Part of the Anthropological Linguistics and Sociolinguistics Commons, Bilingual, Multilingual, and Multicultural Education Commons, and the First and Second Language Acquisition Commons

\section{Recommended Citation}

Allard, E., Mortimer, K., Gallo, S., Link, H., \& Wortham, S. (2014). Immigrant Spanish as Liability or Asset? Generational Diversity in Language Ideologies at School. Journal of Language, Identity \& Education, 13 (5), 335-353. http://dx.doi.org/10.1080/15348458.2014.958040

The original manuscript (found here) was originally titled "Student Spanish as liability or asset: Generational diversity in ideologies of Mexican immigrant language at school." It was published in its final version under the title "Immigrant Spanish as Liability or Asset? Generational Diversity in Language Ideologies at School."

This paper is posted at ScholarlyCommons. https://repository.upenn.edu/gse_pubs/256

For more information, please contact repository@pobox.upenn.edu. 


\title{
Immigrant Spanish as Liability or Asset? Generational Diversity in Language Ideologies at School
}

\author{
Abstract \\ Latino students' educational success is central to America's prosperity-in traditional immigrant \\ destinations and in New Latino Diaspora locations, previously unfamiliar with Latinos. Implicated in this \\ success is the reception young immigrants receive, especially the ways in which they are identified in \\ schools. We describe findings from 6 years of ethnographic research in a high school and an elementary \\ school in the New Latino Diaspora and describe divergent ideologies of Mexican-immigrant Spanish \\ circulating in each context. We show how monoglossic language ideologies in the 2 schools frame \\ teenage immigrants as deficient and younger immigrant children as proficient. These ideologies influence \\ both elementary and high school decisions about how to serve immigrant students, and they shape \\ students' own language practices, which have implications for their learning opportunities and future \\ trajectories. We argue that attention to these divergent language ideologies is necessary for \\ understanding different educational outcomes across decimal generations of immigrant students.

\section{Keywords} \\ New Latino Diaspora, language ideologies, Latinos, decimal generations, English-language learners, \\ contexts of reception

\section{Disciplines} \\ Anthropological Linguistics and Sociolinguistics | Bilingual, Multilingual, and Multicultural Education | First \\ and Second Language Acquisition

\section{Comments} \\ The original manuscript (found here) was originally titled "Student Spanish as liability or asset: \\ Generational diversity in ideologies of Mexican immigrant language at school." It was published in its final \\ version under the title "Immigrant Spanish as Liability or Asset? Generational Diversity in Language \\ Ideologies at School."
}


Student Spanish as liability or asset: Generational diversity in ideologies of Mexican immigrant language at school

\section{Elaine Allard}

Swarthmore College

Katherine Mortimer

University of Texas at El Paso

Sarah Gallo

The Ohio State University

Holly Link

University of Pennsylvania

Stanton Wortham

University of Pennsylvania

Send correspondence to:

Elaine Allard

918 S. $49^{\text {th }}$ St.

Philadelphia, PA

19143

eallard1@swarthmore.edu

(267) 241-7094 


\begin{abstract}
Latino students' educational success is central to America's prosperity — in traditional immigrant destinations and in New Latino Diaspora locations, previously unfamiliar with Latinos. Implicated in this success is the reception young immigrants receive, especially the ways in which they are identified in schools. We describe findings from six years of ethnographic research in a high school and an elementary school in the New Latino Diaspora and describe divergent ideologies of Mexican immigrant Spanish circulating in each context. We show how monoglossic language ideologies in the two schools frame teenage immigrants as deficient and younger immigrant children as proficient. These ideologies influence both elementary and high school decisions about how to serve immigrant students, and they shape students' own language practices, which have implications for their learning opportunities and future trajectories. We argue that attention to these divergent language ideologies is necessary for understanding different educational outcomes across decimal generations of immigrant students.
\end{abstract}

Keywords: New Latino Diaspora, language ideologies, Latinos, decimal generations, English language learners, contexts of reception

Word count: 8,825 (article); 10,019 (article + references) 


\section{Student Spanish as liability or asset: Generational diversity in ideologies of Mexican immigrant language at school}

\section{Introduction}

Approximately one in five public school students today is Latino. Demographers predict that between 2006 and 2050 the Latino student population will grow by $166 \%$, compared to $4 \%$ among other groups. By 2050 Latinos could outnumber non-Latino whites in U.S. schools. As Latino students become more numerous, their educational success becomes central to America's prosperity—not only in traditional areas of concentration like California and the U.S. Southwest, but also in the New Latino Diaspora (NLD), areas of the country that until recently have had little experience with immigrant Latinos and where educational outcomes may or may not follow the trends familiar from traditional areas of Latino settlement (Wortham, Murillo, \& Hamann, 2002).

Mexican immigrants, like other immigrants, have different educational and occupational outcomes depending on their age of arrival—with those immigrating at younger ages more likely to succeed (Rumbaut, 1997, 2004). Scholars have suggested that differing contexts of reception contribute to these trends, as host communities and gatekeeping institutions react differently to immigrants of different ages (Rumbaut, 2004). It is important to study these differing contexts of reception in new immigrant destinations, because the ways in which immigrants are understood and treated in these areas are less entrenched and thus may be more open to positive change.

Schools are crucial contexts of immigrant reception, as one of the primary points of contact between immigrant children and the host society (Suárez-Orozco \& Suárez Orozco, 2001). Adults' understandings of who students are, what skills they have, and what possibilities 
they have in school shape the reception that immigrant students encounter and powerfully affect their prospects in school and beyond (e.g., Valenzuela, 1999). For immigrant and language minority students, ideologies about language can play a large part in how members of their new communities characterize them. Attitudes ostensibly about immigrants' language use can shape and even stand in for beliefs about the immigrants themselves, which in turn can influence how others treat them (Lippi-Green, 1997). Perceived willingness to learn English, for example, is often used as a litmus test to evaluate new immigrants' motives, their allegiance to the U.S., and even their strength of character. Scholars conceive of such commonly held assumptions about language and speakers as "language ideologies"—culturally-situated theories about the relationship between language and the social world (Kroskrity, 2000; Schieffelin, Woolard, \& Kroskrity, 1998; Silverstein, 1979; Woolard, 1998; Woolard \& Schieffelin, 1994).

In this paper, we trace the language ideologies of immigrant Spanish that were deployed, accepted and rejected at an elementary school and a high school in a suburban East Coast community we call Marshall (a pseudonym), a relatively new destination for Mexican immigrants. We believe that ideologies of immigrant students' language provide a useful window into longstanding residents' conceptions of immigrants as people and that these conceptions influence their educational experiences. Drawing on six years of ethnographic research in two schools, we find ideologies in both places were monoglossic—or assumed monolingualism as a norm—but that differences in ideologies across the two sites offer a partial explanation for lower educational outcomes among students who immigrate as teenagers, or 1.25 generation immigrants. Teachers of younger children tended to have more positive ideologies about their immigrant Latino students than did high school teachers. These different ideologies of immigrant Spanish influenced both elementary and high school decisions about how to serve 
immigrant students. Furthermore, language ideologies shaped students' own language practices, which had implications for their learning opportunities and future trajectories.

\section{Conceptual Framework}

\section{Language ideologies}

Language ideologies are belief systems about language and the people who speak in a particular way. Such beliefs are never about language alone. Ideologies about language are also tied to ideologies about social identity, nationalism and other important processes. Language ideologies have particular power as an analytic tool because they expose beliefs about people that operate covertly in social interactions, beliefs that often operate below the level of consciousness (Kroskrity, 1998) but can nonetheless have real consequences.

Woolard (1998) defines language ideologies as "representations, whether explicit or implicit, that construe the intersection of language and human beings in a social world...they envision and enact ties of language to identity" (p. 3). Language ideologies establish connections between language and people, connections that have implications about who people are, what they are worth, and how they should be treated. Language ideologies can be discovered by examining the way people use language and by examining talk about language (Silverstein, 1976). Sometimes overt, they are more often tacit "commonsense notions about the nature of language in the world" (Rumsey, 1990, p. 346). They are also partial representations-that is, they account for only some ways a language is actually used and often erase distinctions and contradictions (Gal \& Irvine, 1995; Irvine \& Gal, 2000). Language ideologies are organizational schemes for understanding how language and socially identifiable kinds of people fit together.

Ofelia García has introduced the concept of monoglossic language ideologies to describe how language policies, particularly in U.S. schools, frame the language practices of Latino 
children (2009, 2010). Monoglossic ideologies construe monolingualism as the norm and conceive of languages as coherent wholes that exist independently of one another, divorced from their social contexts. García argues that much Latino school failure is exacerbated by monoglossic ideologies. The speech of many Latino students, in which students translanguage, moving fluidly between two or more linguistic codes to serve their communicative purposes, are often seen as deficient because they do not adhere to "native standards" of English or "foreign standards" of Spanish (2010, p. 182). More successful approaches to Latino (and multilingual) education are framed by heteroglossic ideologies, which conceive of languages as fluid and dynamic rather than discrete. A heteroglossic perspective views bilinguals' languages as interdependent and complementary, recognizes that bilingualism and biliteracy exist on continua (Hornberger, 1989, 1996, 2000, 2003), that children may enter schools at different points on these continua, and that using one language in the learning of another is both a natural process and an asset. García's work helps explain why Latino children have often been found lacking by schools. Since most U.S. schools operate under monoglossic ideologies of language and language ideologies establish links between language and people, Latinos have often been viewed as mixed up people whose speech departs from monolingual norms.

Language ideologies are important frames for understanding immigrants and other language minority students. This article describes language ideologies in two educational contexts, exploring attitudes towards younger and older immigrant students. We argue that these different ideologies encountered by immigrants who arrive as children and those who arrive as teenagers contribute to their historically divergent success in schools.

Generational diversity in contexts of reception 
Sociologists have identified differences in educational and occupational success (Rumbaut, 1997, 2004) and acquisition of English (Oropesa \& Landale, 1994) between immigrants who come to the United States at different ages. For this reason, some argue that studies of young immigrants should differentiate between the "decimal generations" (Rumbaut, 1997, 2004). Rumbaut calls immigrants who come to the U.S. between 0-5 years old the 1.75 generation, since they share much in common with U.S. born children of immigrant parents (the 2.0 generation) in that they "retain virtually no memory of their country of birth, were too young to go to school in the parental language in the home country (and typically learn English without an accent)" (2004, p. 1167). Those who immigrate between 6-12 years old are the 1.5 generation. These are "pre-adolescent, primary-school-age children who have learned or begun to learn to read and write in the mother tongue at schools abroad, but whose education is largely completed here" (p. 1167). Finally, those who come between 13-17 years of age are the 1.25 generation. They "may or may not come with their families of origin, either attend secondary school after arrival or in the older ages may go directly into the workforce" (p. 1167).

Different outcomes have been observed between each decimal generation and those who immigrate as adults. These differences are widespread among Mexican-origin immigrants as well as other groups, with a roughly linear pattern in outcomes: immigrants who arrive at younger ages have higher college graduation rates, represent higher percentages of upper white collar workers than those who come at later ages (Rumbaut, 2004), and are more proficient in English than those who come later (Oropesa \& Landale, 1994). ${ }^{1}$ The 1.25 generation is an exception to

\footnotetext{
${ }^{1}$ In the absence of consistent support for immigrant languages in schools (Ovando, 2003), this pattern of acculturation may contribute to the rapid loss of immigrant languages in the U.S. "language graveyard" (Rumbaut, 2009), where even in areas of dense immigrant settlement such as Southern California, immigrant languages are often no longer spoken at home by the third generation (Rumbaut, Massey, \& Bean, 2006).
} 
the linear trend. Immigrants coming to the U.S. between 13 and 17 experience the worst educational and occupational outcomes, even compared to adult immigrants, suggesting a "more problematic adaptation" for teenagers (Rumbaut, 2004, p. 1191). These differential outcomes suggest that researchers should attend more closely both to the characteristics of immigrants at various ages and to the local contexts of reception that immigrants of different ages experience.

\section{Research Questions}

Our ethnographic research in one new immigrant destination reveals differences in local contexts of reception, with language ideologies varying significantly across elementary and high school. We explore the ideologies of immigrants' Spanish that circulate in two educational institutions: Marshall High School (MHS), where Mexican immigrant students belonged to the 1.25 generation, and Grant Elementary School, where Mexican-origin students were 1.75 and 2.0 generation. In order to understand how adults in these educational contexts socially identified

these students and evaluated their academic potential, we explore ideologies about Spanish, the language that the immigrant students spoke at home and brought with them to school. In other work we focus on ideologies of immigrant English at these two schools (Gallo et. al., in press), and in particular how these ideologies convey different messages about belonging to the community and to the nation. Drawing on participant observation, interviews, and videotaped classroom data we collected at MHS from 2005-2007 and at Grant from 2008-2010, we compare and contrast these two levels of schooling to better understand the ways in which contexts of reception shape the educational experiences of immigrant students of different decimal generations. We address three questions in section $\mathrm{V}$ below:

1) What ideologies of Mexican immigrant Spanish are communicated in the ways adults at MHS and Grant Elementary talk about language? (V.I- V.II) 
2) How do language ideologies influence educational decisions and practices at MHS and Grant Elementary? (V.III)

3) How do students' own language ideologies and practices relate to the ideologies of Spanish circulating in their schools? (V.IV)

After answering these research questions, we reflect on possible reasons for these differences and discuss the implications they may have for educational possibilities in the New Latino Diaspora.

\section{Research Setting}

\section{The New Latino Diaspora}

Mexicans are the oldest and largest immigrant group to the United States (Zúñiga \& Hernández-León, 2005; Grieco et al., 2012). Longstanding patterns of Mexican presence in the U.S. have changed dramatically in the past fifteen years, however. Large numbers of Mexican immigrants have settled in the Midwest, the South and the Northeast—often in towns where Mexican-origin people have not lived before. Between 1990 and 2000, the number of Latino immigrants to "new settlement states" grew by $130 \%$, as opposed to $50 \%$ in traditional settlement states (Suro \& Tafoya, 2004; Therrien \& Ramirez, 2000), and Latinos increasingly migrate to suburban locations (Frey, 2006; Puentes \& Warren, 2006). With a wider range of destinations, the character of Latino immigration has also changed. A migration that was once mostly male and seasonal now often involves families settling more permanently (Durand \& Massey, 2004).

Though spread across the U.S. in places as geographically diverse as Iowa, Kentucky, and Pennsylvania, the small towns that have become new destination sites in the Latino Diaspora often have much in common, both in their attractiveness to immigrants and in the way residents react to the new arrivals. These communities are often home to agricultural or manufacturing industries with labor demands unmet by long-term residents (Grey \& Woodrick, 2005; Zúñiga \& 
Hernández-León, 2005; Shutika, 2005). And while the arrival of many young residents of working age sometimes brings revival to a struggling downtown (Grey \& Woodrick, 2005), the receiving communities also sometimes react with hostility (Murillo, 2002). Some new immigrants are perceived as hard-working contributors to the town, but others as undesirable neighbors who have brought with them the ills of the big city (Hernández-León \& Zúñiga, 2005; Murillo, 2002; Rich \& Miranda, 2005; Wortham, Mortimer, \& Allard, 2009). Many host communities are ambivalent about the growth of the Mexican population, and internal conflicts over education, social services, local public policy and general neighborliness surface in newspapers, local government, businesses, schools, and community organizations.

\section{Marshall}

Marshall is a suburban community of about 35,000 in a Northeastern metropolitan area that has undergone significant demographic changes since 1990. Once mostly white and African American, by 2010 the town was home to many Mexican immigrants who had come for work. Many white residents had left for wealthier suburbs, while the Mexican community had grown dramatically. Latinos went from under 3\% of the local population in 1990 to $18 \%$ in 2007 and $28 \%$ in 2010 (US Census Bureau, 2006-2008; 2010). As in other New Latino Diaspora locations, long-time residents in Marshall had mixed reactions to the new immigrants (Wortham, Mortimer, \& Allard, 2009). Some lauded them as hard-working, family-oriented, religious people who had revitalized Marshall's commercial areas and its churches while others decried the strain immigrants allegedly put on the town's overextended social services.

Demographic shifts in the town were reflected in school district enrollments. Latino students were concentrated in the elementary grades, reflecting the relatively recent increase in the number of Mexican families settling in Marshall. In addition to being more numerous, 
Mexican immigrant students in the younger grades were also different from their counterparts in the upper grades. Older immigrant students included a large number of teenage labor migrants, whereas elementary-age Mexican students in Marshall were largely born there or brought to Marshall at an early age. Changes in the composition of Mexican students across grades were rapid. As these youngsters advance through the educational pipeline, schools face a changing student body in which cohorts become not only more Mexican, but also more U.S.-educated and English-speaking. The present paper focuses on the ideological differences of Spanish use between the elementary and high school contexts in Marshall at a unique moment in time, in which the student populations as well as the schooling contexts were very distinct.

\section{Marshall High School}

The only public high school in the district, MHS educated students from the city's urbanized center as well as more middle class students from the more suburban areas. The student population of about 2,000 had traditionally been half white and half African American, but these numbers were changing. During the 2006-2007 school year, 46\% of MHS students were black, 38\% were white (non-Latino) and 12\% were Latino (NCES, 2006-2007). There were approximately 100 students (5\% of the total school population) who received English as a second language (ESL) services at MHS, and nearly all of these were Mexican.

A large number of immigrant students at MHS came to the United States as teenagers, and it was not unusual to meet students who came to Marshall on their own, or with siblings or relatives other than their parents. Many of these students maintained heavy work schedules outside of school hours and sent money home to Mexico. Students' educational backgrounds varied quite widely, with some having taken high-school level courses and others not having 
been enrolled in school since the middle grades or earlier. These recent immigrant students were concentrated in the school's ESL program.

While the ESL program at MHS was still relatively small, it had been in existence since the 1970s. Prior to the recent immigration from Mexico, the program had served a smaller group of English language learners, or emergent bilinguals (García, 2009; García \& Kleifgen, 2010) ${ }^{2}$, including some from Asia. In addition to some experience with emergent bilinguals, most of the ESL staff also had some degree of Spanish proficiency. The ESL program director was a fluent speaker of Spanish. The history teacher was a native of Colombia and the science teacher a native of Puerto Rico, and they taught primarily in Spanish. The math teacher was of Mexican origin and conducted his class bilingually. The environment outside the ESL classrooms was nonetheless largely monolingual English. None of the teachers we met outside of the ESL program had experience with emergent bilinguals or spoke Spanish. The front office staff spoke only English, and few if any documents or signs in the school's public areas were written in Spanish.

When we first began research at MHS, emergent bilingual students took elective classes in addition to English as a second language and sheltered and Spanish-medium content classes. This changed in our second year of fieldwork. At that point all MHS students were assigned to one of several "small learning communities" intended to increase contact between teachers and students. As a result, the ELL student schedule became more restricted. From 2006 to 2010, emergent bilingual students at MHS spent most of their school days in ESL classes, with two ninety-minute blocks of ESL reading and grammar, and the remainder of the day in math,

\footnotetext{
${ }^{2}$ A note on terminology: When referring to students' language proficiencies we choose the term emergent bilingual in order to recognize proficiency in both of their languages, and we use English language learner/ELL occasionally for readability. We use ESL as an emic term in reference to programs or classes.
} 
science or social studies classes taught for them in Spanish and English. Whereas emergent bilingual students of all levels once took courses such as computer science and clay modeling, after the reorganization all but the most advanced students were unable to enroll in any fine arts, physical education, or other electives. Thus they had little contact with native English-speaking peers during the school day.

\section{Grant Elementary School}

Grant Elementary, one of six elementary schools in Marshall, was in the downtown area of Marshall and served a population of 400 kindergarteners to fourth graders, most from lowincome families. During the school years in which we collected data at Grant (2008-2010), the school served almost equal numbers of African American and Latino students, with few students from other backgrounds (NCES, 2010). At the lower grade levels, Latinos were the majority of students, with over 70 percent of kindergartners coming from Spanish-speaking households. Unlike the Mexican students at the high school, many Latino students at Grant were born in the U.S. or came to Marshall with both of their parents at an early age. Spanish-dominant students at Grant were also integrated with other students for the majority of the school day, and were separated for ESL pull-out services for only 15 to 60 minutes several times per week. Unlike the 5\% of high school students who received ESL services, approximately 30\% of Grant students were enrolled in ESL. None of the classes or curricular materials were provided in Spanish, only two classroom teachers spoke any Spanish and all students were expected to use English for academic tasks. The school did, however, have a Spanish-speaking receptionist and a Latino vice principal who spoke Spanish and was an important contact for Spanish-speaking parents. Many written materials available in the front office were printed in both English and Spanish.

\section{Contrasting students and schools}


MHS and Grant thus differed both in their student populations and their structures. Many of the Mexican students at the high school were undocumented teenage labor migrants with adult responsibilities. Most had several years of schooling in Mexico, and many had left family—often parents-behind when coming to the U.S. The students at GES, on the other hand, had fewer adult responsibilities, were more likely to live with their parents in Marshall and to be U.S. citizens, and had little to no school experience in Mexico.

The school contexts were also markedly different. At GES Mexican-origin students were a much larger share of the student population. GES was also less diverse in terms of the racial and economic background of non-Mexican students. At GES most other students were from lowincome African American families, while MHS enrolled students from both low- and middleincome areas of Marshall, including African Americans, non-Latino whites, and some Asians. While GES had previously been a predominantly African American school and the immigrant and ELL population was relatively new, MHS had had an ESL program for decades. Thus teachers at GES had less experience with language learners than those at the high school. While GES had a few bilingual personnel, most GES teachers, including those we describe here, did not speak Spanish. MHS's ESL program, on the other hand, included several native and non-native Spanish speakers. The Spanish that was spoken by the adults in each context was also different. At the high school, many of the Spanish-speaking adults had had substantial education in Spanish and controlled academic registers. The Spanish-speaking vice principal at GES, in contrast, was a heritage speaker who was educated in the U.S. and had not completed any schooling in Spanish. Like the two non-native Spanish-speaking classroom teachers, he reported that he did not feel comfortable doing written translations.

\section{Findings}


This section describes the ideologies about Spanish circulating at Marshall High School and Grant Elementary. We found striking differences in how staff and students talked about Spanish and in the stances they took toward the speech of 1.25 generation Mexican immigrant teenagers and 1.75 and 2.0 generation Mexican-origin children. Talk about Spanish revealed beliefs about Mexican young people in each context, and we argue that these divergent and monoglossic conceptions of Mexican-origin students influenced their education.

\section{V.I Ideologies of Mexican Immigrant Spanish at Marshall High}

The ESL program at MHS included substantial native language supports, including content courses taught in Spanish, and educators considered Spanish the most effective medium to communicate academic content to Spanish-dominant students. Nonetheless, the ways in which some educators talked about immigrant students' Spanish revealed underlying deficit models. Many educators held monoglossic language ideologies. As discussed above, such ideologies view monolingualism as the norm and ignore translanguaging and the varied levels of proficiency that bilinguals demonstrate across domains. Monoglossic ideologies see languages as monolithic entities, which people either know or do not know, and therefore often conflate spoken language with literacy as we saw at MHS, where Mexican students' Spanish skills were often described as "weak." In a characteristic comment, one educator explained that students were arriving at MHS with very little "language and education." While he presumably was referring to students' levels of Spanish literacy or prior experience with English, his use of language as a substitute for these gives the impression that the Mexican students could hardly speak Spanish. Although this could not have been his intended meaning - as he had heard them speaking Spanish—-this evaluation was occasionally accepted by other staff. Comments by two senior administrators show that some non-Spanish speaking staff seemed to believe that their 
Mexican students did not speak Spanish or English. One administrator told us that the Mexican immigrant students could not "read, write or speak their native language." Another was less extreme but also spoke to us about the linguistic limitations of Mexican families.

She warns that we may have to deal with parents who don't read Spanish either...She says that they have parents who speak Tex-Mex. I ask what she means. Well, it's "not an actual language" she says. It's a mix. Like Jamaican students she's worked with. They called it pidgin where she worked.

In both of these comments, monolingual English speakers negatively evaluate the Spanish language skills of MHS's Mexican immigrant students. One claims that the students have no such skills at all, while the second characterizes their language practices as a pidgin. "Tex-Mex" is apparently a spoken language that mixes English and Spanish. By saying that it is "not an actual language," she reveals a monoglossic language ideology that denies the legitimacy of hybrid language practices. She frames the community as deficient by claiming that they do not speak a recognized language, and she characterizes them as illiterate.

In addition to conflating spoken and written language in ways that implied Mexican students did not know much Spanish, comments about Mexican students' language also made pejorative reference to students' social class backgrounds, both in the U.S. and in Mexico. For example,

He says that first language literacy is a big problem. They had Spanish for Spanish speakers in the late nineties. He fought for that. But some students couldn't make it in that class because they only had "kitchen Spanish." The class lasted only a year. He adds that he is supportive of using Spanish but he doesn't want the students learning the 'hillbilly Spanish' that they speak now."

In this fieldnote, an educator explains that MHS had once offered a Spanish class for native speakers, but that it had failed because of students' limited Spanish skills. While it is not surprising that some immigrant secondary students from Latin America came to Marshall with 
below-grade-level academic literacies (see García, 1999; Faltis \& Coulter, 2007), the terms he uses to describe this issue reveal a language ideology. The term "kitchen Spanish" could refer simply to Spanish used in the home or in restaurant kitchens, where several students worked, but it also has negative evaluative overtones. Spanish spoken in the kitchen might be less complex, intellectual, or refined than the Spanish needed to function in other domains. The term suggests a blue-collar variety of Spanish, one less useful or appropriate for school. The fact that students who only "had kitchen Spanish" were unable to succeed in this class supports this interpretation. The fact that the course was cancelled rather than adapted to meet the diverse skills of immigrant students also shows the impact that language ideologies can have on school programming. According to this educator's monoglossic view, students' skills could not be leveraged for success in a Spanish class or in content classes — as he said that first language literacy was still a "big problem" long after that Spanish class had been cancelled. This comment illustrates how monoglossic ideologies can and often do exist within environments that support native language instruction, since this educator "fought for" this course and for other forms of native-language use in content courses for emergent bilinguals.

Just as "kitchen Spanish" calls to mind the blue-collar restaurant work that many Mexican immigrants performed in Marshall, "hillbilly Spanish" indexes the lower social class and rural areas from which many Mexican students came. The term "hillbilly" evokes not only poor rural backgrounds but also crassness, lack of sophistication and intelligence. This comment implies that "hillbilly Spanish" is an inferior kind of Spanish. In another conversation with this educator, he made it clear that he did not mean to discount the students' Spanish completely. He remembered teaching Lorraine Hansberry's A Raisin in the Sun and recognized that if that play had been written in standard English, much would have been lost. Thus he conceded that this 
particular variety of Spanish had expressive value. But other comments made clear that he believed Mexican students' Spanish to be insufficient outside informal circles-in bilingual careers, for example. We, as proficient non-native Spanish speakers, did not find students' Spanish to be non-standard and were surprised to hear it described in these terms. We thus interpret these comments as ideologies about the students' social identities more than observations of their actual language use.

\section{V.II Ideologies of Mexican Immigrant Spanish at Grant Elementary}

The Spanish spoken by teenage immigrants at MHS was often stigmatized and associated with academic difficulties, but Spanish was most often identified as an asset at Grant Elementary. Elementary school teachers claimed that Spanish-speaking children should maintain their home-language, and that it was even beneficial for them to use Spanish in the classroom. The following interview excerpts express this sentiment:

Teacher 1: "They eventually talk to each other in English and if they feel better talking to each other in Spanish, then that's fine. 'Cause I do feel like they still need to keep their language, like a lot of times the parents will say they [the students] don't want to speak Spanish anymore, but I think it's important to keep their language."

Teacher 2: "I think it's great [that students use Spanish]. Like my kids use it all the time amongst each other, whether it's in the classroom or outside, and I embrace that. I don't want them to lose that. As long as they're trying to learn English, then I'm happy. I'm happy with them using it. It's hard. I feel like it's really hard for me, but that's my own, you know, just learning Spanish, but that's my own obstacle."

Teacher 3: "I feel like I say it all the time. They are so lucky to be able to speak two languages. I wish I could, and honestly, like, it's the world we live in now, you know? Like I hope that they will keep speaking Spanish, and I mean, obviously, English, too, like I would never want them to lose it-it's part of who they are." 
Grant teachers believed students to be proficient Spanish speakers and wanted them to maintain it, wished they themselves could speak Spanish, thought being bilingual was an asset, and recognized its importance to students' identities.

It is important to note, however, that Grant teachers also focused on English acquisition as their primary goal for students. The three excerpts above all mention English, and the teachers stress that they view Spanish as important as long as students are also developing English. English was clearly primary for them, and understandably so, since it was their job to teach these students to read, write, and learn subject matter in English. Nevertheless, they also believed that their young students' English would develop in due time and did not worry that students' Spanish would be anything other than an advantage for them.

In addition to positive general attitudes toward students' Spanish and predictions about its utility "in the world we live in," Grant teachers found Spanish to be an asset to students and teachers alike. Teachers even learned basic Spanish phrases.

Ms. Jacobs said that it was really effective for her to use basic phrases in English and Spanish with the students as "they felt more comfortable because this lady knows a little bit in my language." She went on to say that she would "gradually drop the Spanish and bring in the English."

All kindergarten teachers, like Ms. Jacobs, attempted to use Spanish for directives, basic greetings and leave-takings, and sometimes academic routines such as counting and the days of the week. As in Palmer's (2011) account of teachers' belief that students "need" Spanish until they are "ready" for English, Grant teachers often claimed that it was effective to use Spanish so that kids would feel more comfortable and understand more easily. Underlying these sentiments was the belief that Spanish was a tool facilitating students' transition to English rather than a goal in and of itself. 
Teachers also viewed Spanish as an asset for translation. Grant students had a wide range of Spanish and English proficiencies, with some students recently arrived from Mexico speaking only Spanish. Teachers relied on bilingual students to translate for each other.

Ms. Sanders [kindergarten teacher] said her strategy for dealing with situations where children don't understand or can't communicate in English is to have students translate for each other. She said that "their friends help them by speaking..."

Ms. Long [first grade teacher] also said that Bernarda frequently translated directions for Julina into Spanish when she noticed that Julina seemed lost, and that Gaby did this as well.

Sometimes teachers also enlisted us, as bilingual researchers, to conduct writing lessons in Spanish, in order to help struggling Spanish-dominant children learn procedures for the schoolwide writing program. Here again teachers saw Spanish as necessary and useful.

Teachers at Grant used very few explicit labels to talk about Mexican students' language use. As teachers were not proficient in Spanish themselves, they did not recognize the variations in students' Spanish proficiencies and tended to identify any student who spoke Spanish as a proficient speaker. Thus a monoglossic ideology of language proficiency operated at Grant as well, but with different consequences. High school educators perceived non-standard Spanish or "weak" literacy as deficient Spanish, while at the elementary school any Spanish was seen as Spanish proficiency that would be an asset both in and out of school. This contrast is ironic because the older students, schooled in Mexico, were much more literate in Spanish than their counterparts at Grant. And, while all high school students spoke fluent Spanish, the students at GES had a much wider range of Spanish proficiency. Nevertheless, the first language abilities of the older students were seen by educators as unsophisticated and a problem while the younger children's weaker Spanish was considered an unequivocal advantage. V.III Language ideologies, teacher attitudes, and ESL programming 
Comments at MHS suggesting that students spoke a substandard variety of Spanish carried strong deficit views and suggested students' home language was a problem. By denying that students knew any worthwhile language, high school educators at least subconsciously expressed a belief that their teenage immigrant students were less capable than their Englishspeaking counterparts. These beliefs had consequences in both thought and action.

Many non-ESL educators at MHS adopted the vocabulary of special education to discuss emergent bilingual students. They had lower expectations of ELL students than their mainstream peers. One asked if it were possible to fail them if they weren't doing well, or if they were like special education students whom you could not fail. In explaining the decisions he had made about scheduling, an administrator told us, "The model for upper functioning special ed kids would work for upper functioning language kids." He was referring to an administrative similarity in scheduling instructional supports, but the parallel between disabled and bilingual students nonetheless linked the two groups. This had consequences, as some teachers did not understand where the similarities and differences between bilingual and disabled students ended.

The association between Spanish-speaking and disability was also implied in how students and occasionally teachers referred to English-medium classes. ELL students consistently called classes that were offered to English-speaking students, and which were available only to advanced bilingual students, as normales or regulares. In one instance, a Latina teacher congratulated one of the students in an all-Mexican class for getting an A in biologynot in ESL biology, but regular biology. This implied that ESL classes were abnormal or irregular, not as challenging as English-medium classes—because they were conducted mostly in Spanish and populated only by emergent bilinguals. 
At MHS, programming for emergent bilinguals was organized like traditional special education, with all but the most English-proficient in separate classrooms. Emergent bilingual students were enrolled in ESL and Spanish-medium content classes. Before the 2006 reform, all students had elective classes and thus some contact with non-ESL teachers. These teachers nonetheless considered immigrant students outside their responsibilities. One ESL educator explained,

"With the ESL population, I don't see mainstream teachers really knowing them that well. I think that they take the language barrier as a, sometimes as a way out to just say, 'Well I don't speak their language so I'm not going to, I don't ha-, I can't get involved."'

After the reorganization mainstream teachers had even more reason to feel this way, since they had almost no emergent bilinguals in their classes.

Things were different at Grant Elementary. ELLs were in mainstream classes all day, with "pull out" classes available to emergent bilingual students. The principal explicitly lamented how they had at one time designed their ESL instruction using a special education model. "So they [ELL students] became just like Special Ed students. Another group. And that was one of our big, big mistakes across the board." She went on to describe how, since they had integrated English learners into mainstream classes, teachers' attitudes had changed.

"I don't hear teachers saying, you know, 'well if you get the ESL kids out of my room, I wouldn't be having these problems, or my test scores would be better', or anything else. I think that really has blurred here and I think it's because of umm they're a much larger population here and they [teachers] see them as their students now, not a subgroup."

Because it was logistically impossible to provide a separate educational program for emergent bilinguals at Grant, administrators included them in mainstream classes, thus shifting teacher attitudes toward emergent bilingual students and contributing to the positive ideologies of student Spanish.

V.IV Students' Ideologies of Spanish at Marshall High 
Students recognized the ideologies about their language and identity, and they had their own ideologies of Spanish. In what may have been a self-protective response, MHS students strongly valued Spanish proficiency and defiantly asserted their expertise in Spanish. Student comments about Latinos who did not use Spanish and their responses to Latino teachers revealed these ideologies. As mentioned above, three ESL educators were Latino. One teacher's Spanish was "non-native," and his students did not let him forget it.

Mr. Ramos's accent is not entirely native-like. He starts some sentences and does not finish them, sometimes switching to English, and he uses feminine articles with masculine nouns, and vice versa. At one point, he says, "Un buen idea" and five or six students correct him right away. They repeat themselves, "uNA buena idea," several times. Mr. Ramos says, "Un buen idea" again. They repeat the correct form. Then he notices that they are correcting him, and he says "Una buena idea" and thanks them.

Students' corrections of Mr. Ramos's Spanish were so persistent, in fact, that the lone South Asian student in the class even joined in with the class's criticisms, asserting (falsely) that even he could "speak better Spanish" than the teacher.

With a Colombian teacher, Mr. Santos, students had different struggles over language. When Mr. Santos used words that students did not know, they actively resisted and ridiculed them, or accused him of making them up. Students recognized that they spoke a different variety of Spanish, but they refused to accept his variety as superior or let their own variety be discounted.

Mr. Santos pauses for a moment, looking for a word for "internet" in Spanish. The students all suggest internet, with Spanish pronunciation, but Mr. Santos rejects it. He asks me [researcher], and I say I've only ever heard internet. He says in English, "there's another word in castellano-castellano." One of the students groans and throws back his head. Mr. Santos continues to refuse the possibility of using internet. He then struggles over pronouncing requerir. The kids repeat it and get him to say it again. He struggles with it. Eventually, he gives up and says, "OK, require" in English. 
Here Mr. Santos implies that the Spanish his students speak is not "real" Spanish (unlike "castellano"), and that there exists a better word out there than the one students suggest. This reflects a monoglossic language ideology by rejecting any borrowing, in this case from English. The students refuse to accept this. Then Mr. Santos—who had lived for years in the United States and occasionally stumbled over a Spanish word—falters in his pronunciation, suddenly positioning the students as experts, a position that they actively embrace. It is telling that students seldom corrected Spanish speakers (teachers or researchers) whom they perceived to be non-native speakers or non-Latinos, despite the fact that we made more mistakes than most Latino teachers. Students persistently corrected Latino teachers to assert their Mexican identity and cultural authenticity, not simply to comment on errors. By positioning themselves as language experts, students rejected deficit ideologies and presented their own language use as superior.

Mexican students also claimed that exclusive Spanish use was an important marker of cultural loyalty amongst Spanish speakers, regardless of English proficiency. One graduate of MHS said: “Usually we don't speak English amongst us...I don't know if we're like ashamed that the other one is going to think that 'oh now she knows English and she thinks that she's better blah, blah, blah.'" She suggests that speaking English would position someone as outside of the group and this would be shameful. She distances herself from this interpretation by using reported speech-it is the voice of someone else accusing the English user of being arrogant. Nevertheless, by using "we" she implicates herself, suggesting that even those who doubt the validity of this interpretation find it difficult to escape. 
Several students expressed distrust of Mexican students who spoke English with other Spanish speakers. They also claimed that Mexican students who took mainstream classes thought they were better than their compatriots in ESL.

I ask Paco if he knows any Mexicans who don't speak Spanish and he says not really, and Marisa, without turning around in her desk, says that she knows one. Then she turns around and tells me that there's a Mexican in one of her classes who doesn't speak to other Mexicans. He knows Spanish but he doesn't use it because he thinks he's better than the other Mexicans.

Students that made these linguistic choices, presumably to blend in, were considered disloyal and rejected by other Latinos. One group of beginners generalized from these instances, telling us that once Latinos learn English, most forget Spanish, forget where they come from, and think they're better than others. For these students, speaking Spanish was a moral responsibility. A Latino advocate visiting MHS echoed this same outlook when he joked in a staff meeting that a Latino colleague who did not speak Spanish "was not going to heaven."

\section{V.V Students' Ideologies of Spanish at Grant Elementary}

Grant students' ideologies of Spanish contrasted with high school students' ideologies. In an environment where Spanish was lauded as an advantage, Grant students valued both Spanish and English and used both languages for social and academic purposes. Non-Latino students also displayed interest in Spanish and tried to use it (see Link, Gallo, \& Wortham, in press.)

Mexican students' remarks about their own language use reflected dominant language ideologies at the school. Teachers praised Spanish proficiency as important for their students, but English was the language of instruction. One child told us that he spoke "only Spanish at home and English at school," while another said he spoke mostly English and that he did not want to learn to read or write in Spanish. This contrasted with the boys' actual language use, as they frequently spoke Spanish in class and often asked researchers to read both Spanish and English 
books to them. Other children described how they used both languages in school and said that they would like to learn to read and write in Spanish. One said she wanted to read in both languages "porque así cuando soy grande, puedo tener un trabajo en español y uno en inglés, y puedo entender más personas [because that way I can have one job in English and one in Spanish, and I can understand more people]." Students took up the somewhat conflicting messages about language that adults communicated at school. They realized that English was the language of power and talked in a way that mirrored tacit school policies in which English was for schooling and Spanish for home. But many internalized the message that both Spanish and English were valuable for careers, though they most often saw the languages as separate.

Like MHS students who saw Spanish and English as mutually exclusive, another GES student described her fears of forgetting Spanish and not being able to communicate with her family: "Si yo me olvida mi español yo no voy a poder hablar...en español... Me importa más mi familia [If I forget my Spanish I'm not going to be able to speak...in Spanish...My family is more important to me]." This six-year-old demonstrates language loyalty and goes on to say that she thinks she will lose Spanish, as she has an older friend who has already forgotten it. While teachers and families expected children to become bilingual by maintaining Spanish in the home, parents and children worried that in the process of attending school and living in the U.S. young children would lose their first language and undermine close ties to family. Thus these students echoed monoglossic ideologies circulated by adults, communicating their belief that languages were distinct and mutually exclusive entities.

While many Mexican-origin children expressed monoglossic beliefs about language, their actual behavior was heteroglossic. Students used both languages for academic and social purposes in classrooms, the cafeteria, and during recess. They sometimes used Spanish 
exclusively for social purposes and for communicating with Spanish-speaking peers and researchers, but in many instances they used both languages to discuss academic tasks they were completing in English. As described in the field notes below, they drew upon both languages with ease.

As they played they moved back and forth between Spanish and English, reading the words in English, but conversing in both languages. For example, at one point, Joel said, 'es tu turno [it's your turn]', and then at another point said, 'your turn.'

I asked him what his story was about, and he told me in Spanish. He said he needed help to write it in English and asked me in Spanish how to write: 'I played in the snow' in English. I translated, and he sounded out the words with me.

These are typical interactions in that Grant students often mixed Spanish and English for both academic and social purposes, even though neither students, teachers, nor parents expressed conscious awareness of it. These examples also show how English remained the language of reading and math, retaining its official status as the legitimate language of academics.

Through their metacommentary and actions, non-Spanish-speaking students also expressed ideologies about Spanish. Many non-Spanish-speaking students [NSS], almost all African-American, talked about, expressed interest in, and attempted to use Spanish with each other, their Spanish-speaking [SS] peers, and researchers, as in the following excerpts.

Sitting on the carpet in math, Cleo [NSS] says to no one in particular, 'I can say hola.'

At one point, Ms. Long claps to get the kids' attention, and I hear Annette [NSS] from across the table exclaiming, 'excelente!' congratulating those at her table who sat up straight with their hands folded.

While Abi and Lorena [SS] alternate saying 'mi casa [my house]' back and forth, Joyner [NSS] starts chanting, 'mi casa mi casa mi casa', too.

Non-Spanish-speakers often addressed comments like these to researchers and demonstrated their knowledge of and interest in Spanish. 
Quan [NSS] came up and hugged me, then immediately burst into a string of syllables sounding like Spanish. As we walked into the room together, Ilana [NSS] told me, 'siéntate [sit down]'. Quan said, "Hola means hello," and began speaking more faux Spanish in a rhythmic, chanting way. He then said to me, 'siéntate means sit down.'

Quan's performance, stringing Spanish-sounding syllables together, was representative of episodes in which non-Spanish speaking children engaged in language play, and even in metacommentary about language use. Within earshot of researchers, children often made comments suggesting they knew more Spanish than they actually did, as when one non-Spanishspeaking boy announced, "I do, too, [speak Spanish], I only do it at home, and sometimes I do it at school, right, Gaby [SS]?". This student drew upon the ideology of "English at school, Spanish at home." He showed not only his desire to know the language, but also an interest in group membership.

Like the high school students, Grant Spanish speakers also asserted their authority over and pride in their language. Sometimes they corrected other students, as well as researchers.

When we are talking about phone numbers Abi asks Jorge in Spanish his dad's phone number and Jorge responds "no sabo"[I don't know (nonstandard)]. Abi corrects him in Spanish and says "no sê" [I don't know], telling me (and him) that he sounds like her abuelo Florentino who says "no sabo", but it is not correct.

Here a Spanish-dominant student corrects her Mexican classmate's Spanish grammar. Thus she positions herself as an authority on Spanish. This contrasts with academic activities conducted predominantly in English, where she often struggled.

Unlike the relatively segregated ESL classes at MHS, which limited emergent bilingual students' opportunities to engage peers, at Grant English-dominant peers were regularly exposed to Spanish-speaking in many different contexts. Although Spanish was clearly important to Mexican students at both schools, at Grant it was also positioned as a valuable commodity to non-Spanish-speaking students as well. 


\section{Discussion}

We have shown very different ideologies of Mexican immigrant Spanish circulating at Marshall High and Grant Elementary. Each school had a monoglossic ideology that considered languages "all or nothing” propositions, but educators at MHS often characterized Spanishspeaking students as deficient while educators at Grant saw them as proficient. These differences were linked to educational programming at both schools and influenced both educators' attitudes toward immigrant students and students' own language ideologies and practices.

How can we explain these ideological differences across schools? Educators' own language abilities might seem to account for the differences. Teachers at Grant were English monolinguals, whereas at MHS several Spanish-speaking educators had strong beliefs about what constituted "correct" Spanish and evaluated their students' language in relation to this standard. But language ideologies are often more about the speakers of the languages than scientific assessments, so real or perceived characteristics of the students themselves were also at issue. MHS students were evaluated in part for their class backgrounds and compared unfavorably to higher achieving students of the past. The younger children at Grant, on the other hand, attended a school where all students were low-SES, and where teachers had no prior experience with immigrant students.

Marshall educators may have also viewed younger immigrant children more sympathetically than they viewed teenagers because of the age difference, with the ideologies reflecting this differential assessment. The teenagers were perhaps viewed as more foreign and threatening than immigrant children. Teenagers are typically viewed in more negative ways than children—seen as potential gang members, drug users, and trouble makers. In fact, MHS 
educators openly worried about gang affiliation among some Mexican immigrant boys. As small children, Grant students were less vulnerable to such perceptions.

Finally, expectations around second language development were also different for the two groups of students. Young children are seen as still developing, able to easily "pick up" second languages, and are just learning to read and write in elementary school. Teenagers, on the other hand, are seen as less malleable and having more variable success in learning second languages. These differences help account for the relative lack of anxiety Grant teachers had about their students' English and academic development, compared to the deficit framings of the teenage students' first language skills at MHS.

Monoglossic language ideologies at both MHS and GES were problematic, though in different ways. At MHS, where the ideology characterized students as less competent, instruction—even in Spanish—was likely to be remedial and separate from "normal" students. Students understood that their language abilities were belittled and knew that classes designed for them were not "normal," and they in turn resisted the institution housing these ideologies. Some resisted in ways that undercut their educational prospects. Many emergent bilingual students dropped out, and negative ideologies of immigrant Spanish exacerbated this problem.

At Grant, where a monoglossic ideology characterized students as being fully proficient in Spanish, the ideology perpetuated a naïve attitude toward language maintenance, assuming that young children would be able to maintain Spanish without educational interventions. Although the English-plus rhetoric espoused at GES had clear benefits, helping to instill a sense of self-worth and positive attitudes toward bilingualism, even positive ideologies of Spanish are insufficient to support the kinds of Spanish language development that would prepare students for the bilingual careers their teachers envisioned. 
Our data show dramatic contrasts in the ideological contexts of reception encountered by immigrant students from different decimal generations and suggests one part of an explanation for lower educational outcomes among 1.25 generation immigrants. These snapshots of two schools at particular moments in time show how attitudes and responses to a new immigrant population can vary significantly depending on local school contexts and on the generation of immigrant students in question. They also show that attitudes towards immigrants in the New Latino Diaspora are still in flux. The question of whether immigrants' situations in the NLD will become more like those in traditional destinations remains uncertain. While our high school data suggest a problematic context of reception that seems to mirror national trends in regions of traditional Latino settlement, our elementary school data reveal possibilities for more positive attitudes toward immigrant students.

\section{References}

Durand, J., \& Massey, D. (Eds.). (2004). Crossing the border: Research from the Mexican Migration Project. New York: Russell Sage Foundation.

Faltis, C., \& Coulter, C. (2007). Teaching English Learners and immigrant students in secondary schools (1st Ed.). Upper Saddle River, NJ: Pearson.

Frey, W. H. (2006). Diversity spreads out: Metropolitan shifts in Hispanic, Asian, and Black populations since 2000. Washington DC: Brookings Institution.

Gal. S. \& Irvine, J. T. (1995). The boundaries of languages and disciplines: How ideologies construct difference. Social Research, 62(4): 967-1001.

Gallo, S., Link, H., Allard, E., Wortham, S. \& Mortimer, K. Conflicting Ideologies of Mexican Immigrant English across Levels of Schooling (Forthcoming). International Multilingual Research Journal.

Grey, M. A., \& Woodrick, A. C. (2005). "Latinos have revitalized our community": Mexican migration and Anglo responses in Marshalltown, Iowa. In V. Zúñiga \& R. Hernández-León (Eds.), New Destinations: Mexican Immigration in the United States (pp. 133-152). New York: Russell Sage Foundation. 
García, O. (1999). Educating Latino students with little formal schooling. In C. Faltis, \& P. Wolfe (Eds.), So much to say: Adolescents, bilingualism \& ESL in the secondary school (pp. 61-81). NY, NY: Teachers College Press.

García, O. (2009). Bilingual education in the twenty-first century: a global perspective. Malden, MA: Wiley Blackwell.

García, O. (2010). Monoglossic ideologies and language policies in the education of U.S. Latinas/os. In E. G. Murillo, Jr., S.A. Villenas, R.T. Galván, J.S. Muñoz, C. Martínez \& M. Machado-Casas (Eds.), Handbook of Latinos and education: research, theory and practice (pp. 157-169). New York: Routledge.

García, O. \& Kleifgen, J.A. (2010). Emergent bilinguals: Policies, programs, and practices for English language learners. New York: Teachers College Press.

Grieco, E.M., Acosta, Y.D, de la Cruz, G.P, Gambino, C., Gryn, T., Larsen, L.L., Trevelyan, E.N., \& Walters, N.P. (2012). The foreign born population of the United States: 2010. American Community Survey Reports. Retrieved from http://www.census.gov/prod/2012pubs/acs-19.pdf

Hornberger, N. H. (1989). Continua of Biliteracy. Review of Educational Research, 59, 271-296.

Hornberger, N. H. (1996). Language and education. In S. L. McKay \& N.H. Hornberger (Eds.), Sociolinguistics and language teaching (pp. 449-473).

Hornberger, N.H. \& Skilton-Silvester, E. (2000) Revisiting the continua of biliteracy: international and critical perspectives. Language and education: an international journal, $14(2), 96-122$.

Hornberger, N. (Ed.). (2003). Continua of biliteracy: an ecological framework for educational policy, research, and practice in multilingual settings. Clevedon, UK: Multilingual Matters.

Irvine, J. T., \& Gal, S. (2000). Language ideology and linguistic differentiation. In P. V. Kroskrity (Ed.), Regimes of language: Ideologies, polities, and identities (pp. 3583). Santa Fe, NM: School of American Research Press.

Kroskrity, P.V. (1998). Identify. Journal of Linguistic Anthropology, 9 (1-2), 111-14.

Kroskrity, P.V. (Ed.) (2000). Regimes of language: Ideologies, polities, and identities. Santa Fe, NM: School of American Research Press.

Link, H., Gallo, S., \& Wortham, S. $\square$ gus $\square$ me k $\square \square \mathrm{l} \square \mathrm{t} \square$ !: Faux Spanish in the New Latino Diaspora. (Forthcoming). In A. Creese \& A. Blackledge (Eds.), Heteroglossia as Practice and Pedagogy. London, UK: Springer.. 
Lippi-Green, R. (1997). English with an accent: language, ideology, and discrimination in the United States. London, UK: Routeledge.

Murillo, E. (2002). How does it feel to be a problem? In S. Wortham, E. Murillo, \& E. Hamann (Eds.), Education in the New Latino Diaspora: Policy and the politics of identity. Westport, CT: Ablex.

Oropesa, R.S. \& Landale, N.S. (1997). In search of the new second generation: alternate strategies for identifying second generation children and understanding their acquisition of English. Sociological Perspectives, 40 (3), 429-455.

Ovando, C. (2003). Bilingual education in the United States: Historical development and current issues. Bilingual research journal, 27 (1), 1-24.

Palmer, D. (2011). The discourse of transition: Teachers' language ideologies within transitional bilingual education programs. International Multilingual Research Journal, 5(2), 103-122.

Puentes, R. \& Warren, D. (February, 2006). One-fifth of America: A comprehensive guide to America's first suburbs. Washington DC: Brookings Institution.

Rich, B. \& Miranda, M. (2005). The sociopolitical dynamics of Mexican immigration in Lexington, Kentucky, 1997-2002: An ambivalent community responds. In V. Zúñiga \& R. Hernández-León (Eds.), New Destinations: Mexican Immigration in the United States (pp. 187-219). New York: Russell Sage Foundation.

Rumbaut, R. G. (2004). Ages, life stages, and generational cohorts: decomposing the immigrant first and second generations in the United States. International Migration Review. 38(3), 1160- 1205.

Rumbaut, R.G. (2009). A language graveyard? The evolution of language competencies, preferences and use among young adult children of immigrants. In T.G. Wiley, J. S. Lee, $\&$ R. Rumberger (Eds.), The education of language minority immigrants in the United States. Clevedon, UK: Multilingual Matters.

Rumbaut, R., Massey, D., \& Bean, F. (2006). Linguistic life expectancies: Immigrant language retention in southern California. Population and development review. 32(3), pp. 447-460.

Rumsey, A. (1990). Wording, meaning, and linguistic ideology. American Anthropologist, 92, 346-361.

Schieffelin, B., Woolard, K. A., \& Kroskrity, P. V. (Eds.) (1998). Language ideologies: Practice and theory. New York: Oxford University Press.

Shutika, D. L. (2005). Bridging the community: nativism, activism, and the politics of inclusion in a Mexican settlement in Pennsylvania. In V. Zúñiga \& R. Hernández-León (Eds.), New Destinations: Mexican Immigration in the United States (pp. 103-132). New York: Russell Sage Foundation. 
Silverstein, M. (1976). Shifters, linguistic categories, and cultural description. In K. Basso \& H. Selby (Eds.), Meaning in anthropology (pp. 187-221). Albuquerque, NM: University of New Mexico Press.

Silverstein, M. (1979), Language Structure and Linguistic Ideology. In P. Clyne, W. Hanks and C. Hofbauer (Eds.), The Elements: A Parasession on Linguistic units and levels (pp. 193-247).

Suárez- Orozco, C. \& Suárez-Orozco, M. (2001). Children of immigration. Cambrige, MA: Harvard University Press.

Suro, R. \& Tafoya, S. (2004). Dispersal and concentration: Patterns of Latino residential settlement. Washington, D.C.: Pew Hispanic Center.

Therrien, M., \& Ramirez, R. (2000). The Hispanic population in the United States: March 2000. Washington, D.C.: U.S. Census Bureau.

U.S. Census Bureau (2006-2008). Fact sheet: Marshall borough, Pennsylvania. American Community Survey. Retrieved 4 March 2010 from http://factfinder.census.gov

U.S. Census Bureau (2010). American Fact Finder: Marshall borough, Pennsylvania. Retrieved from http://factfinder2.census.gov/faces/tableservices/

National Center for Education Statistics (2010),U.S. Department of Education. Institute of Education Sciences [Table of descriptive information for Grant Elementary, for the 20092010 school year] Common Core of Data. Retrieved from http://nces.ed.gov/ccd/schoolsearch.

National Center for Education Statistics (2006-2007),U.S. Department of Education. Institute of Education Sciences [Table of descriptive information for Marshall High, for the 20062007 school year] Common Core of Data. Retrieved from http://nces.ed.gov/ccd/schoolsearch.

Valenzuela, A. (1999). Subtractive schooling: U.S. - Mexican Youth and the Politics of Caring. Albany, NY: SUNY Press.

Woolard, K. A. (1998). Language ideology as a field of inquiry. In B. Schieffelin, K. A. Woolard \& P. V. Kroskrity (Eds.), Language ideologies: Practice and theory (pp. 3-47). New York: Oxford University Press.

Woolard, K. A., \& Schieffelin, B. (1994). Language ideology. Annual Review of Anthropology, 23, 55-82.

Wortham, S., Mortimer, K. \& Allard, E. (2009). Mexicans as model minorities in the New Latino Diaspora. Anthropology \& Education Quarterly, 40, 388-404. 
Wortham, S. E. F., Murillo, E. G. \& Hamann, E. T. (Eds.) (2002). Education in the New Latino Diaspora: Policy and the politics of identity. Westport, CT: Ablex.

Zúñiga, V., \& Hernández-León, R. (2005). Introduction. In V. Zúñiga \& R. Hernández-León (Eds.), New destinations: Mexican immigration in the United States (pp. xi-xxix). New York: Russell Sage Foundation. 